\title{
Alternation in Enzyme Activities to Assess the Tolerance/Susceptibility of Rice (Oryza sativa L.) Genotypes to Heat and Drought stresses
}

\author{
A. R. Nirmal Kumar ${ }^{*}$, C. Vijayalakshmi² and D. Vijayalakshmi²
}

${ }^{1}$ Dept. of Crop Physiology, Regional Agricultural Research Station, Tirupati, Andhra Pradesh, (517 501), India

${ }^{2}$ Dept. of Crop Physiology, Tamil Nadu Agricultural University, Coimbatore, Tamil Nadu (641 003), India

\section{Corresponding Author}

A. R. Nirmal Kumar

e-mail: nirmalar035@gmail.com

\author{
Article History \\ Manuscript No. AR1680 \\ Received in $7^{\text {th }}$ September, 2016 \\ Received in revised form $13^{\text {th }}$ February, 2017 \\ Accepted in final form $4^{\text {th }}$ April, 2017
}

\begin{abstract}
The field experiment was conducted to observe the effect of combined heat and drought stress on Catalase, Peroxidase, Nitrate reductase and Soluble protein contents to screen and study the biochemical basis of heat and drought tolerance in three rice genotypes (ADT 43, TKM 9 and N22). The stresses were imposed at panicle initiation (PI) and anthesis stages of crop growth. The genotype N22 was found to be tolerant followed by TKM 9 while ADT 43 was observed to the susceptible genotype based on the above biochemical traits. Irrespective of genotypes, anthesis stage stress brought about accumulation of antioxidant enzymes and soluble protein compared to stress at PI stage. ADT 43 recorded low catalase activity of $\left(6.91 \mu \mathrm{g} \mathrm{H}_{2} \mathrm{O}_{2} \mathrm{~min}^{-1} \mathrm{~g}^{-1}\right)$, peroxidase activity of $\left(4.35 \Delta 430 \mathrm{~nm} \mathrm{~g}^{-1} \mathrm{~min}^{-1}\right)$, soluble protein content $\left(11.05 \mathrm{mg} \mathrm{g}^{-1}\right)$ and Nitrate reductase activity of $\left(14.52 \mu \mathrm{g} \mathrm{NO}_{2} \mathrm{~g}^{-1} \mathrm{~h}^{-1}\right)$. While, N22 recorded higher catalase activity of $\left(7.32 \mu \mathrm{g} \mathrm{H}_{2} \mathrm{O}_{2}\right.$ min $^{-1}$ $\left.\mathrm{g}^{-1}\right)$, peroxidase activity of $\left(5.68 \Delta 430 \mathrm{~nm} \mathrm{~g}^{-1} \mathrm{~min}^{-1}\right)$, soluble protein content $\left(11.01 \mathrm{mg} \mathrm{g}^{-1}\right)$ and Nitrate reductase activity of $\left(15.84 \mu \mathrm{g} \mathrm{NO}{ }_{2}\right.$ $\left.\mathrm{g}^{-1} \mathrm{~h}^{-1}\right)$. Higher antioxidant enzymes activity coupled with more soluble protein and Nitrate reductase activity was clearly demonstrated in the tolerant genotype (N22) compared to susceptible genotype (ADT 43). These results confirm that these biochemical traits may be used to screen rice genotypes for combined stresses and understand the mechanism underlying stress tolerance.
\end{abstract}

Keywords: Rice, heat and drought stress, enzyme activity

\section{Introduction}

Rice is one of the most staple food crops in India and nearly half of the world's population depends on rice which requires an increase in production by $0.6-0.9 \%$ annually until 2050 for growing population. The projected requirement by the year 2050 for consumption purpose alone is $0.136 \mathrm{mt}$ for an expected population of about 162 million (Ramesh chand, 2012). Though, the scope of bringing additional area under rice cultivation is limited and the increase in production has to come from less land, water, labour and other inputs without causing any adverse impact on environment. During the coming years agriculture globally will have to face dramatic climate change (Battisti and Naylor, 2009; Nelson et al., 2014). Water availability will be a limiting factor for agricultural activities in arid and semi-arid regions. Even the areas that have to some extent of available water, are also expected to experience prolonged periods of drought. Moreover, increased atmospheric temperature and heat waves incident are expected to reduce the yields by depleting the water availability (IPCC, 2013). One of the major consequences of combined heat and drought stress is the excess generation of reactive oxygen species (ROS), which leads to oxidative stress (Hasanuzzaman et al., 2012, 2013). Plants must be protected from heat induced oxidative stress so that they can survive under multiple abiotic stresses. Tolerance to heat and drought stress in crop plants has been associated with an increase in antioxidantal capacity (Almeselmani et al., 2006; Babu and Devraj, 2008). Tolerant plants were able to survive with a tendency of protection against the damaging effect of ROS scavenging and detoxification (Apel and Hirt, 2004) activity of these enzymes, which are temperature sensitive and increase with increasing in temperature. As a consequence, the balance of peroxidase (PX), and catalase (CAT) activities, representing the main enzymatic $\mathrm{H}_{2} \mathrm{O}_{2}$ scavenging mechanism in plants, is crucial for the suppression of toxic $\mathrm{H}_{2} \mathrm{O}_{2}$ levels in a cell. The enzymes PX, and CAT are able to scavenge $\mathrm{H}_{2} \mathrm{O}_{2}$ with different mechanisms. Specifically, PX, contrary to CAT, requires an ascorbate and glutathione (GSH) regeneration system, the ascorbate-glutathione cycle. In fact, the first reaction of this cycle catalyzed by $\mathrm{PX}$, is $\mathrm{H}_{2} \mathrm{O}_{2}+$ Ascorbate $\rightarrow$ $\mathrm{H}_{2} \mathrm{O}+$ Monodehydroascorbate (MDA). Instead, CAT directly converts $\mathrm{H}_{2} \mathrm{O}_{2}$ into $\mathrm{H}_{2} \mathrm{O}$ and $1 / 2 \mathrm{O}_{2}$ and on the contrary of APX, it is more involved in detoxification of $\mathrm{H}_{2} \mathrm{O}_{2}$ than the 
regulation as asignaling molecule in plants (Cuypers et al., 2011). In general $50 \%$ of soluble protein in plant is occupied by an enzyme RuBisCo (Ribulose Bis phosphate Carboxylase Oxygenase). It is present in the stroma of the chloroplast where $\mathrm{CO}_{2}$ fixation takes place during photosynthesis. The amount of RuBisCo in leaves is controlled by rate of synthesis and degradation. However, drought stress in rice (Vu et al., 1999) leads to rapid decrease in abundance of RuBisCo small subunits transcripts, which may indicate the decreased synthesis. Heat stress induced suppression of photosynthesis, is mainly by decreasing the proportion of soluble protein to total leaf $\mathrm{N}$, adversely affecting the rubisco protein and activity (Xu and Zhou, 2006). The reduction of $\mathrm{NO}_{3}{ }^{-}$to $\mathrm{NO}_{2}{ }^{-}$catalyzed by Nitrate reductase (NR) is considered to be the rate-limiting step of $\mathrm{N}$ assimilation. $\mathrm{NR}$ activity is co-ordinated with the rate of photosynthesis and the availability of $\mathrm{C}$ skeletons by both transcriptional and post translational controls (Huber et al., 1996). Nitrate reductase activity is vital for the metabolic and physiological status of plants and can be used as a biomarker of plant stress including drought. Nitrate reductase activity decreases in plants exposed to water limitation (Azconet al., 1996). The nitrate reductase activity was decreased in wheat under water deficit condition compared to control (Dwivedi et al., 2012).

The impacts of environmental stress particularly drought and heat on crop physiology and yield have been studied independently. However, under field conditions, both of these stresses often occur in combination. Hence, overcoming the effects of high temperature and water stress on rice production is essential for food security in the future. Hence, the present study was aimed to evaluate the impact of the heat and drought stress in combination on anti-oxidant enzyme activity, Nitrate reductase and soluble protein contents and to draw inferences on the major physiological processes and biochemical constituents conferring to access the tolerance/susceptibility of rice.

\section{Materials and Methods}

The present field investigation was carried out during 2013 in the month of January to May in Tamil Nadu Agricultural University, Coimbatore, Tamil Nadu, to study the enzyme activities and to access the tolerance/susceptibility of rice (Oryza sativa L.) genotypes viz., ADT 43, TKM 9 and Nagina 22 (N 22) to heat and drought stress. For conduct the study, nursery was raised at Paddy Breeding Station of Tamil Nadu Agricultural University, Coimbatore. Twenty one days old seedlings at one seedling per hill were transplanted with a spacing of $20 \times 10 \mathrm{~cm}^{2}$ in the Rain Out Shelter (ROS) facility of the Department of Crop Physiology. Stress treatments were imposed in the ROS, while a similar area of control was maintained adjacent to the ROS facility. The dimensions of the Rain Out Shelter and the Control were $21 \mathrm{~m}$ long and $6 \mathrm{~m}$ wide. Prior to transplanting, the land inside ROS and the area which is parallel outside the ROS (Control) were puddled, levelled and incorporated with recommended dosage of basal fertilizer 150:50:50 N, $\mathrm{P}_{2} \mathrm{O}_{5}, \mathrm{~K}_{2} \mathrm{O} \mathrm{kg} \mathrm{ha}$. The land was divided into 12 plots with $2 \mathrm{~m}^{2}$ plot $^{-1}$. The experiment consist three treatments and four replications. The treatment details are as follows $\mathrm{T}_{1}$ (Control) well-watered throughout the crop growth period, $\mathrm{T}_{2}$-Drought and Natural High temperature stress at Panicle Initiation (PI) stage in which water was withheld for 2 weeks with a moisture stress of -50 to $70 \mathrm{kpa}$ and the temperature ranged from 34.2 to $37.8^{\circ} \mathrm{C}$ (Figure 1a) at the time of panicle initiation, $\mathrm{T}_{3}$ - Drought and Natural high temperature stress at anthesis stage in which water was withheld for 2 weeks and the temperature ranged from 33.5 to $36.6^{\circ} \mathrm{C}$ (Figure $1 \mathrm{~b}$ ) at the time of anthesis. The time of sowing of the selected genotypes were staggered such that their PI and Anthesis coinciding the natural high temperature around the early of April for panicle initiation stress and May to June for anthesis stress. Temperature for the entire experiment period was monitored by installing the log stick data logger (Model. LS350-TH Japan) and an automated weather station inside the ROS and control area. Drought stress treatments were administrated and monitored by measuring the soil water potential using the tensiometers installed at $30 \mathrm{~cm}$ depth in each plot. Water was completely withheld for 2 weeks during the stress period. Plants were re watered when the tensiometers registered soil water tension of -50 to $-70 \mathrm{kpa}$.

Catalase activity was assayed from the rate of $\mathrm{H}_{2} \mathrm{O}_{2}$ decomposition extinction coefficient of $39.4 \mathrm{mmol}$ as measured by the decrease in the absorbance at $240 \mathrm{~nm}$, following the procedure of Aebi (1974). The reaction mixture contains $50 \mathrm{mmol}$ potassium phosphate buffer $(\mathrm{pH} \mathrm{7.0)}$ and
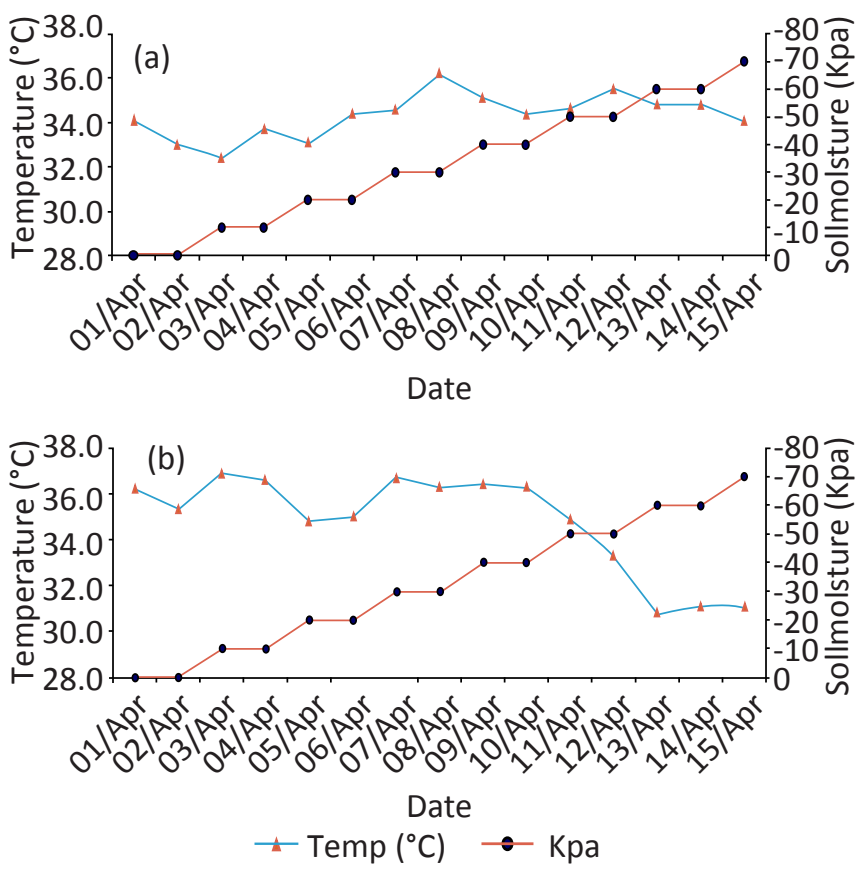

Figure 1: Air temperature and soil moisture in rice genotypes exposed to combined heat and drought stress at (a) panicle initiation and (b) anthesis 
the appropriate volume of extract. The reaction was initiated by adding $10 \mathrm{mmol}$ of $\mathrm{H}_{2} \mathrm{O}_{2}$. One unit of catalase is defined as the amount of enzyme that liberated half of the peroxide oxygen from $10 \mathrm{mmol} \mathrm{H}_{2} \mathrm{O}_{2}$ solutions in $100 \mathrm{sec}$ at $25^{\circ} \mathrm{C}$.

Peroxidase activity (change in OD value at $430 \mathrm{~nm} \mathrm{~g}^{-1}$ $\mathrm{min}^{-1}$ ) was determined by Perur (1962) and Angelini et al. (1990) method. One gram of leaf was extracted using $0.1 \mathrm{M}$ phosphate buffer ( $\mathrm{pH}$ 7.0) and a known volume of the extract was added to a cuvette containing $3 \mathrm{ml}$ phosphate buffer and $3 \mathrm{ml}$ pyrogallol was added and the increase in absorbance at $430 \mathrm{~nm}$ was recorded. The change in absorbance in minutes was used to calculate the enzyme activity.

Nitrate reductase activity was estimated in fully expanded leaves from control and stress imposed plants by Nicholas et al. (1976) method. The enzyme activity was expressed as $\mu \mathrm{mol} \mathrm{NO} \mathrm{g}^{-1} \mathrm{~h}^{-1}$.

Soluble protein content was estimated from the leaf samples by Lowry et al. (1951) method. Soluble protein was estimated from the third leaf of both the control and treated plants. Known weight of leaves was homogenized with phosphate buffer in a mortar and pestle. The homogenate was centrifuged at $3000 \mathrm{rpm}$ for $10 \mathrm{~min}$. The supernatant was made to known volume and $0.1 \mathrm{ml}$ was taken for estimation of proteins. The plant extract was made to $1 \mathrm{ml}$ with distilled water; $5 \mathrm{ml}$ of alkaline copper tartarate solution was added and made to stand for $10 \mathrm{~min}$ at room temperature. Folin reagent at $0.5 \mathrm{ml}$ was added rapidly with immediate mixing and kept aside for 30 minutes for colour development. The intensity of the colour was measured at $660 \mathrm{~nm}$ and expressed as $\mathrm{mg} \mathrm{g}^{-1}$ fresh weight.

\subsection{Statistical analysis}

Factorial Randomized Block Design (FRBD) analysis was carried out on various parameters as per the procedure suggested by Gomez and Gomez (1984). Wherever the treatment differences are found significant, critical differences were worked out at $5 \%$ probability level and the values are furnished. Two tailed Pearson's correlation was carried out by SPSS software and ${ }^{* *}$ represents significant at $0.01 \%$, ${ }^{*}$ represents significant at $0.05 \%$.

\section{Results and Discussion}

The catalase (CAT) activity $\left(\mu \mathrm{g} \mathrm{H}_{2} \mathrm{O}_{2} \mathrm{~min}^{-1} \mathrm{~g}^{-1}\right)$ of the leaf showed an increasing trend as the growth stage advanced from PI to anthesis under control and combined stresses (Table 1). The CAT activity in ADT 43 was 5.68 with $23.7 \%$ increase over control at PI stage and with a value of 6.91 and increase of $26.4 \%$ over control at anthesis stage. Higher catalase activity of 6.70 with $25.9 \%$ increase over control at PI and $34.3 \%$ at anthesis stage was noticed in N 22. The cultivar TKM 9 followed N 22 with an activity of 6.22 with $26.0 \%$ increase at $\mathrm{PI}$ and a value of 7.1 with $19.4 \%$ increase over control at anthesis stage. Higher accumulation of $\mathrm{H}_{2} \mathrm{O}_{2}$ coupled with low rate of enzyme activity indicates the susceptible nature of the
Table 1: Catalase activity $\left(\mu \mathrm{g} \mathrm{H}_{2} \mathrm{O}_{2} \mathrm{~min}^{-1} \mathrm{~g}^{-1}\right)$ in rice genotypes exposed to combined heat and drought stress at panicle initiation and anthesis stages

\begin{tabular}{lccccc}
\hline \multirow{2}{*}{ Genotypes } & \multicolumn{2}{c}{ Panicle initiation } & & \multicolumn{2}{c}{ Anthesis } \\
\cline { 2 - 3 } \cline { 5 - 6 } & Control & Stress & & Control & Stress \\
\hline ADT 43 & $4.51 \pm 0.06$ & $5.68 \pm 0.07$ & & $5.08 \pm 0.04$ & $6.91 \pm 0.05$ \\
TKM 9 & $4.60 \pm 0.12$ & $6.22 \pm 0.02$ & & $5.70 \pm 0.02$ & $7.05 \pm 0.04$ \\
N 22 & $4.96 \pm 0.08$ & $6.70 \pm 0.04$ & & $4.81 \pm 0.09$ & $7.32 \pm 0.11$ \\
CD $(p=0.05)$ & $0.15^{* *}$ & & $0.14^{* *}$ \\
variety & & & $0.12^{* *}$ \\
Treatment & $0.13^{* *}$ & & $0.20^{* *}$ \\
V×T & $0.22^{* *}$ & &
\end{tabular}

genotype to heat and drought stress. In the present study, high temperature and water deficit condition stimulates the catalase activity at various levels due to genotypic variations to stress tolerance. Elevation in enzyme activity was about $26 \%$ and $35 \%$ in N 22 at $\mathrm{PI}$ and anthesis stresses respectively. Therefore, high CAT activity in this genotype could be related to its role in preventing the formation of ROS like $\mathrm{H}_{2} \mathrm{O}_{2}$, and therefore the appearance of excessive damage by oxidative stress, achieving better heat and drought tolerance. This view is supported by Rao et al. (2012) stating that, the catalase enzyme plays an important role in lowering the ROS levels and helping avoid oxidative stress. Peroxidase (PX) activity $(\Delta 430$ $\mathrm{nm} \mathrm{g}^{-1} \mathrm{~min}^{-1}$ ) was less in ADT 43 (3.69) with $14.3 \%$ increase at PI stage and enzyme activity of 4.35 over control at anthesis stage under combined heat and drought stress. The cultivar N 22 showed higher PX activity of 4.79 with $23.3 \%$ increase at $\mathrm{PI}$ and 5.68 at anthesis which is $34.3 \%$ increase over control at anthesis stage. The genotype TKM 9 recorded a value of 4.44 with $21.1 \%$ increase over control at PI and 5.53 at anthesis stage (Table 2). The level of peroxidase activity increased over control indicating the higher production of reactive oxygen radicals under heat and drought stress. Cao et al. (2009) reported an increase in PX activity from 11.6 to $41.3 \%$ under

Table 2: Peroxidase activity $\left(\Delta 430 \mathrm{~nm} \mathrm{~g}^{-1} \mathrm{~min}^{-1}\right.$ ) in rice genotypes exposed to combined heat and drought stress at panicle initiation and anthesis stages.

\begin{tabular}{lcclcc}
\hline Genotypes & \multicolumn{2}{c}{ Panicle initiation } & & \multicolumn{2}{c}{ Anthesis } \\
\cline { 2 - 3 } \cline { 5 - 6 } & Control & Stress & & Control & Stress \\
\hline ADT 43 & $3.16 \pm 0.04$ & $3.69 \pm 0.05$ & & $3.46 \pm 0.07$ & $4.35 \pm 0.10$ \\
TKM 9 & $3.50 \pm 0.06$ & $4.44 \pm 0.04$ & & $3.52 \pm 0.02$ & $5.53 \pm 0.04$ \\
N 22 & $3.67 \pm 0.04$ & $4.79 \pm 0.07$ & & $3.73 \pm 0.05$ & $5.68 \pm 0.08$ \\
CD $(p=0.05)$ & $0.11^{* *}$ & & $0.14^{* *}$ \\
variety & & & \\
Treatment & $0.10^{* *}$ & & $0.11^{* *}$ \\
V×T & $0.14^{* *}$ & & $0.20^{* *}$ \\
\hline
\end{tabular}


day and night temperature of $40 / 21^{\circ} \mathrm{C}$ in rice. In this study, it is observed that in both the trials elevation in enzyme activity was about $30.5 \%$ and $52.2 \%$ in N 22 at PI and anthesis stresses respectively. Whereas, ADT 43 recorded the lowest value of $16.7 \%$ at $\mathrm{PI}$ and $25.72 \%$ at anthesis stage stresses. This result corroborates with results of Cao et al. (2009) who explained that high activity of protective enzymes in the antioxidant system in plants might be one of the physiological mechanism for heat tolerance in rice. This finding is indicating the fact that tolerant genotypes showed higher peroxidase activity compared to susceptible genotypes. Nitrate Reductase (NR) is an important enzyme for nitrogen assimilation ultimately protein synthesis in plant cell which is highly sensitive to heat and drought stress condition. NR activity is vital for the metabolic and physiological status of plants and can be used as a biomarker of plant stress including drought since, Nitrate reductase activity decreases in plants exposed to water limitation (Azcon et al., 1996). In the present study, reduction in NR activity was more in ADT 43 (12.22) with $11.1 \%$ decrease over control at $\mathrm{PI}$ stage and $6.1 \%$ reduction over control at anthesis stage under combined heat and drought stress recording a value of 14.52 . The cultivar $\mathrm{N} 22$ showed higher NR activity of 13.10 with $4.4 \%$ reduction at $\mathrm{PI}$ and a value of 15.84 with $5.2 \%$ decrease over control at anthesis stage followed by TKM 9 with a content of 12.85 with $8.1 \%$ decrease at $\mathrm{PI}$ and $8.8 \%$ increase over control at anthesis stage (Figure 2). Correia et al. (2005) stated that, maintenance of NR activity has an imperative role by the tolerant genotypes for

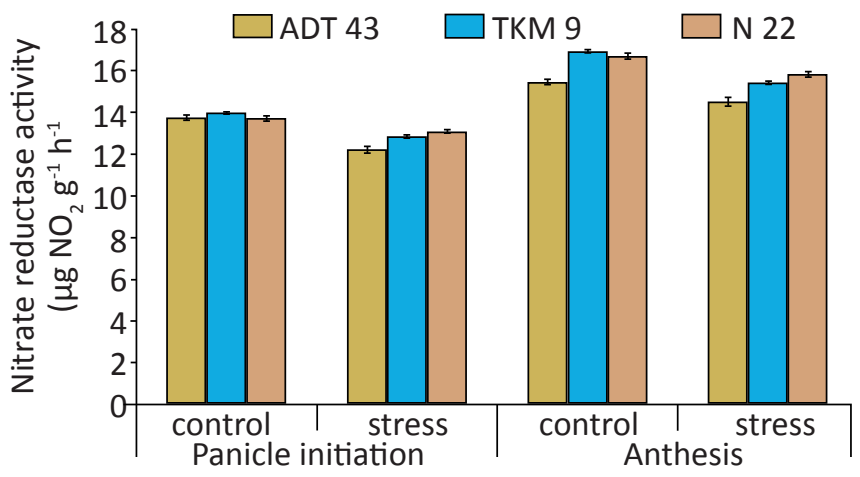

Figure 2: Effect of combined heat and drought stress at panicle initiation and anthesis stages on nitrate reductase activity in rice

nitrogen assimilation and protein synthesis, which ultimately leads to improved productivity under heat and drought. It was also suggested that, some tolerant genotypes showed a marked reduction of NR activity under drought indicating that the enzyme is highly sensitive to stresses. The soluble protein (SP) content of the leaf, being a measure of RuBP carboxylase activity, is considered as an index for photosynthetic efficiency. The varietal and treatmental differences were significant for the soluble protein content. In control, ADT 43 recorded highest SP content of 14.6 and 13.7, and when it was imposed with stress at PI and anthesis, the values were 12.3 and 11.1 respectively. Whereas, $\mathrm{N} 22$ recorded the lowest value of soluble protein content of 13.9 and 12.6 in control and value of 12.9 and 11.5 at $\mathrm{PI}$ and anthesis respectively. In the present study, N 22 maintained higher soluble protein in both the trials and treatments with $6.3 \%$ and $12.8 \%$ reduction at $\mathrm{PI}$ and anthesis stress respectively over control (Figure 3 ). While, ADT 43 showed higher reduction per cent over the control in

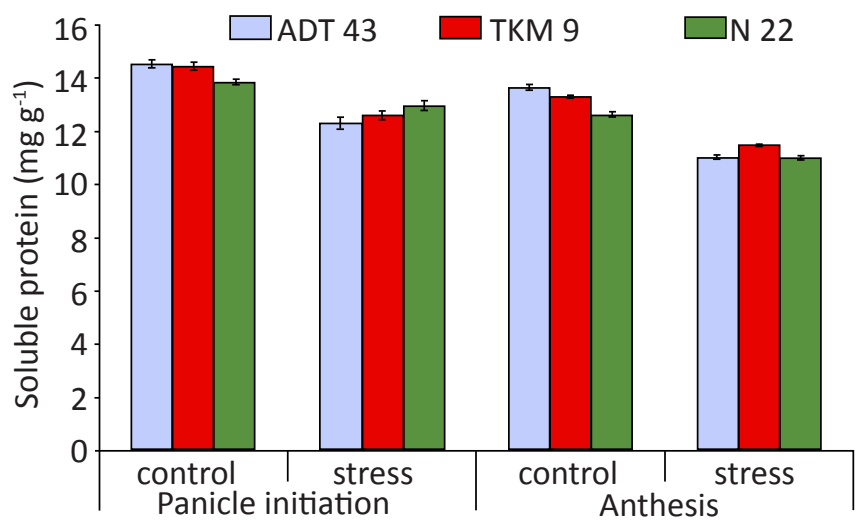

Figure 3: Effect of combined heat and drought stress at panicle initiation and anthesis stages on Soluble Protein content in rice

both the trials and treatments with $15.3 \%$ and $17.0 \%$ at PI and anthesis stresses respectively. The reduction of SP content might be due to the degradation of available SP in plant and reduction of synthesis of new protein. However, decrease of RuBisCO activity is due to presence of the binding inhibitors within the catalytic site (Parry et al., 1999). CAT activity had a positive correlation with NR activity (Figure 4). Maintenance of

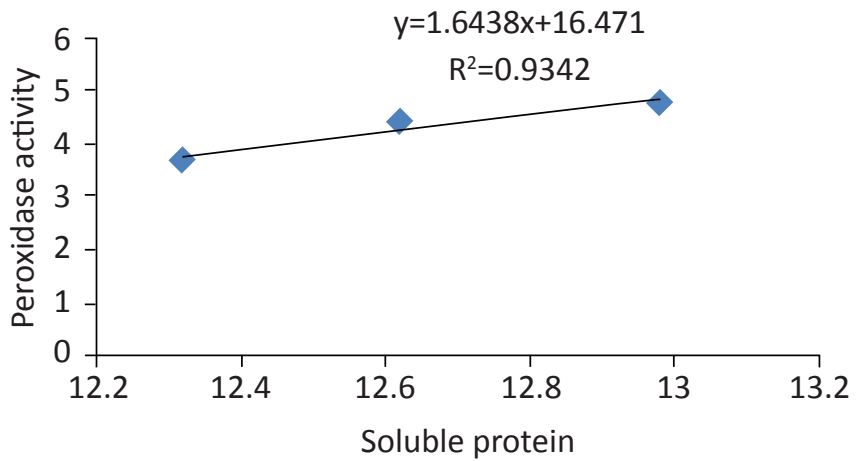

Figure 4: Correlation between peroxidase activity $(\Delta 430 \mathrm{~nm}$ $\left.\mathrm{g}^{-1} \mathrm{~min}^{-1}\right)$ and Soluble Protein content $\left(\mathrm{mg} \mathrm{g}^{-1}\right)$ in rice genotypes subjected to heat and drought stress at panicle initiation stage.

soluble protein content by the genotypes could be attributed to higher Rubisco activity leading to more carbon fixation and ultimately to higher photosynthetic efficiency under heat and drought, is one of the important traits for tolerance. PX had a strong positive correlation with SP content (Figure 5). This study was in corroboration with Xu and Zhou (2006) concluded that heat and drought stress induced suppression of photosynthesis mainly by decreasing the proportion of soluble protein to total leaf $\mathrm{N}$, adversely affecting the Rubisco protein and activity. 


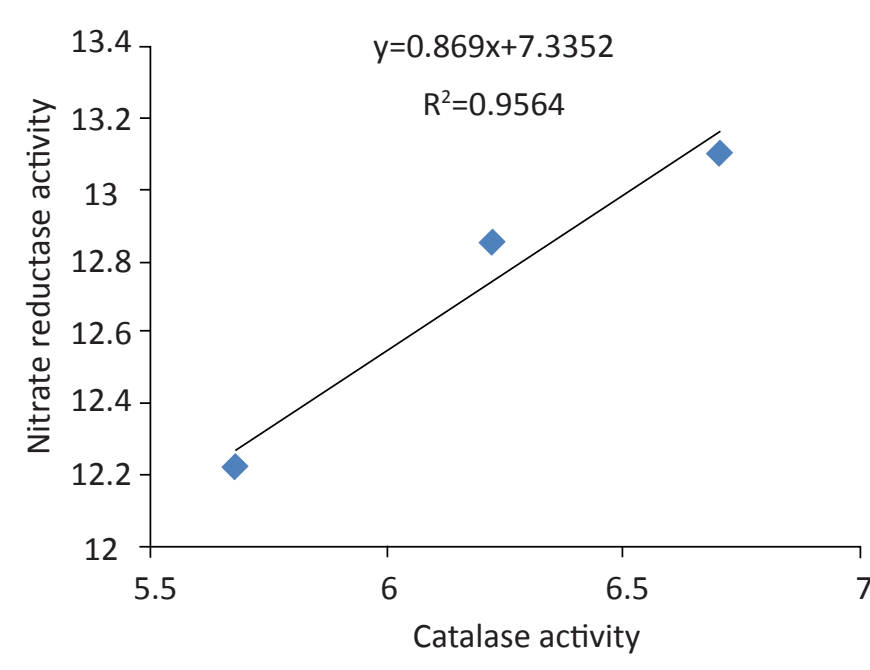

Figure 5: Correlation between Nitrate reductase activity ( $\mu \mathrm{mol}$ $\mathrm{NO}_{2} \mathrm{~g}^{-1} \mathrm{~h}^{-1}$ ) and Catalase activity $\left(\mu \mathrm{g}_{2} \mathrm{O}_{2} \mathrm{~min}^{-1} \mathrm{~g}^{-1}\right)$ in rice genotypes subjected to heat and drought stress at panicle initiation stage.

\section{Conclusion}

Antioxidant enzymes like CAT and PX activity under combined stresses can be used as physiological traits to screen rice genotypes. A high positive correlation of these traits shows up regulation of these enzymes underlies stress tolerance in rice genotypes. PX had a strong positive correlation ( $r=0.93$, $p<0.05)$ with SP content. Whereas, CAT activity had a positive correlation $(r=0.95, p<0.05)$ with NR activity. Tolerant genotypes with high antioxidant enzymes activity were able to maintain the photosynthetic activity and survive well under stress situations.

\section{References}

Aebi, H., 1974. Catalases.In Bergmeyer HU. Methods of enzymatic analysis 2, 673-684.

Almeselmani, M., Deshmukh, P.S., Sairam, R.K., Kushwaha, S.R., Singh, T.P., 2006. Protective role of antioxidant enzymes under high temperature stress. Plant Science171, 382-388.

Angelini, R., Manes, F., Federico, R., 1990. Spatial and functional correlation between diamine oxidase and peroxidase activities and their dependence upon etiolation and wounding in chickpea stems. Planta 182, 89-96.

Apel, K., Hirt, H., 2004. Reactive oxygen species: metabolism, oxidative stress and signal transduction. Annual Review of Plant Biology 55, 373-399.

Azcon, R., Gomez, M., Tobar, R.M., 1996. Physiological and nutritional responses by Lactuca sativa $\mathrm{L}$. to nitrogen sources and mycorrhizal fungi under drought conditions. Biology and Fertility of Soils 22, 156-161.

Babu, N.R., Devraj, V.R., 2008. High temperature and salt stress response in French bean (Phaseolus vulgaris).
Australian Journal of Crop Science 2, 40-48.

Cao, Y.Y., Duan, H., Yang, L.N., Wang, Z.Q., Liu, L.J.,Yang, J.C., 2009. Effect of high temperature during heading and early filling on grain yield and physiological characteristics in Indica rice. Acta Agronomica Sinica 35, 512-521.

Correia, M.J., Fonseca, F., Azedo-Silva, J., Dias, C., David, M.M., Barrote, I., Osorio, M.L., Osorio, J., 2005. Effects of water deficit on the activity of nitrate reductase and content of sugars, nitrate and free amino acids in the leaves and roots of sunflower and white lupin plants growing under two nutrient supply regimes. Physiologia Plantarum 124, 61-70.

Cuypers, A., Smeets, K., Ruytinx, J., Opdenakker, K., Keunen, E., Remans, T., Horemans, N., Vanhoudt, N., Van Sanden, S., Van Belleghem, F., 2011. The cellular redox state as a modulatorin cadmium and copper responses in Arabidopsis thaliana seedlings. Journal of Plant Physiology 168, 309-316.

Battisti, D.S., Naylor, R.L., 2009. Historical warnings of future food insecurity with unprecedented seasonal heat. Science 323(5911), 240-244.

Dwivedi, S.K., Singh, V.P., Singh, G.P., Arora, A., 2012. Combined effect of cytokinin, paclobutrazol and ascorbic acid on nitrogen metabolism and yield of wheat (Triticum aestivum L.) under water deficit stress condition. Indian Journal of Plant Physiology 17(3\&4), 259-267.

Nelson, G.C., Van der Mensbrugghe, D., Ahammad, H., 2014. Agriculture and climate change in global scenarios: why don't the models agree. Agricultural Economics 45(1), 85-101.

Gomez, K.A., Gomez, A.A., 1984. Statistical procedures for agricultural research. ( $2^{\text {nd }} E d$.) John Wiley and sons, New York, USA, 680.

Hasanuzzaman, M., Hossain, M.A., Da Silva, J.A.T., Fujita, M., 2012. Plant responses and tolerance to abiotic oxidative stress: antioxidant defenses is a key factor. in crop stress and its management: perspectives and strategies; Bandi, V., Shanker, A.K., Shanker, C., Mandapaka, M. (Eds.), Springer: Berlin, Germany, 261-316.

Hasanuzzaman, M., Nahar, K., Fujita, M., 2013. Extreme temperatures, oxidative stress and antioxidant defense in plants. in abiotic stress-plant responses and applications in agriculture; Vahdati, K., Leslie, C. (Eds.), In Tech: Rijeka, Croatia, 169-205.

Huber, S.C., Bachmann, M., Huber, J.L., 1996. Post-translational regulation of nitrate reductase activity: a role for $\mathrm{Ca} 21$ and 14-3-3 proteins. Trend in Plant Science1, 432-438.

IPCC, "Summary for policymakers," in climate change 2013: the physical science basis. contribution of working group $i$ tothe fifth assessment report of the intergovernmental panel on climate change, Stocker, T.F., Qin, D., Plattner, G.K. (Eds.), Cambridge University Press, Cambridge, UK. Lowry, O.H., Brought, N.T.R., Farr, L.A., Randall, R.J., 1951. 
Protein measurement with folin phenol reagent. The Journal of Biological Chemistry 193, 265-275.

Nicholas, J.C., Harper, J.E., Hageman, R.H., 1976. Nitrate reductase activity in soybeans. Effect of light and temperature. Plant Physiology 58, 731-735.

Parry, M.A.J., Loveland, J., Andralojc, P.J.,1999. Regulation of Rubisco. In: Bryant, J., Burrel, M., Kruger, N., Eds. Plant carbohydrate biochemistry. Oxford: BIOS Scientific Publishers Ltd, 127-145.

Perur, N.G., 1962. Measurement of peroxidase activity in plant tissues. Current Science 31, 71-81.

Ramesh, C., 2012. Vision discussion. Presentation made in the knowledge meet: Meeting of AU Vice Chancellors and
ICAR Directors, 21-22 August, NASC, Pusa, New Delhi. Rao, N.D., Voleti, S.R., Subrahmanyam, D., Rao, P.R., Ramesha, M.S., 2012. Heterosis for antioxidant enzymes in rice hybrid under abiotic stress conditions. Indian Journal of Plant Physiology 17(2), 166-169.

Vu, J.C.V., Gesch, R.W., Allen, L.H., Boote, K.J., Bowes, G., 1999. $\mathrm{CO}_{2}$ enrichment delays a rapid, drought-induced decrease in Rubisco small subunit transcript abundance. Journal of Plant Physiology 155, 139-142.

$\mathrm{Xu}$, Z.Z., Zhou, G.S., 2006. Combined effects of water stress and high temperature on photosynthesis, nitrogen metabolism and lipid peroxidation of perennial grass Leymus chinensis. Planta 224, 1080-1090. 